\title{
Odour masking of tomato volatiles by coriander volatiles in host plant selection of Bemisia tabaci biotype B
}

\author{
Pedro H. B. Togni ${ }^{1}$, Raúl A. Laumann ${ }^{2}$, Maria A. Medeiros ${ }^{3}$ \& Edison R. Sujii ${ }^{*}$ \\ ${ }^{1}$ Department of Ecology, Institute of Biological Sciences, University of Brasília - UnB, Brasília - DF, Brazil, ${ }^{2}$ Biological \\ Control, Embrapa Genetic Resources and Biotechnology, Cx. Postal 02372, CEP 70770-917, Brasília-DF, Brazil, and \\ ${ }^{3}$ Embrapa Vegetables, Gama-DF, Brazil
}

Accepted: 3 May 2010

Key words: silverleaf whitefly, insect behaviour, Solanum lycopersicum, Coriandrum sativum, semiochemicals, inappropriate landing, ecological management, intercropping, Hemiptera, Aleyrodidae, colonisation

\begin{abstract}
The silverleaf whitefly, Bemisia tabaci (Gennadius) (Hemiptera: Aleyrodidae), is one of the most important pest insects in tomato crop systems worldwide. It has been previously demonstrated that intercropping tomato [Solanum lycopersicum L. Mill. (Solanaceae)] with coriander [Coriandrum sativum L. (Apiaceae)] reduces the incidence and severity of damage caused by B. tabaci. However, it is not yet known how coriander affects the insect's behaviour. We evaluated the attractiveness of tomato constitutive volatiles to $B$. tabaci and what effect coriander constitutive volatiles have on the insect's behaviour. To this end, we conducted three bioassays in a multiple-choice four-arm olfactometer (' $x$ ' type), measuring $B$. tabaci behaviour when offered tomato and coriander constitutive volatiles presented alone as well as together. We also evaluated the colonisation and establishment of B. tabaci in experimental plots with only single tomato plants and tomatoes intercropped with coriander in a greenhouse. Bemisia tabaci males and females recognised tomato constitutive volatiles as a positive stimulus (kairomonal effect), indicating that semiochemicals from this plant can play an important role in the insect's host plant selection. Coriander constitutive volatiles reduced the attractiveness of tomato volatiles but no repellency to these volatiles was observed. Greater numbers of adults and nymphs of $B$. tabaci per plant were observed in tomato monoculture plots than in tomato intercropped with coriander. We suggest that coriander constitutive volatiles have an odour masking effect on tomato volatiles, thus interfering in the host plant selection of $B$. tabaci.
\end{abstract}

\section{Introduction}

The silverleaf whitefly, Bemisia tabaci (Gennadius) biotype B (Hemiptera: Aleyrodidae), is the main pest in many agricultural crop systems worldwide, due both to direct and indirect damage (Byrne \& Bellows, 1991; Oliveira et al., 2001). The direct damage is related to continuous sap sucking and honeydew accumulation on various parts of the plant, interfering in the plant's photosynthesis and reducing productivity and product market value (fruit and fibre) (Oliveira et al., 2001). Furthermore, the most

*Correspondence: Edison R. Sujii, Biological Control - NTCB, Embrapa Genetic Resources and Biotechnology, Cx. Postal 02372, CEP 70770-917, Brasília - DF, Brazil. E-mail: sujii@cenargen.embrapa.br significant damage caused by this insect is the transmission of several viruses, mainly of the Geminiviridae (Jones, 2003). In Latin America, tomato, Solanum lycopersicum L. (Solanaceae), is one of the most attacked crops, and losses of up to $100 \%$ have been registered in many countries due to whitefly-borne viruses (Morales \& Jones, 2004).

Because of the high genotypic plasticity and polyphagous nature of this pest, the use of insecticides to control whitefly populations has shown reduced efficacy over time. Thus, more attention has been given to other methods, such as conservation of natural enemies (Gerling et al., 2001; Naranjo, 2001), crop-free periods (e.g., Ucko et al., 1998), irrigation management (Castle et al., 1996), use of living ground covers, and 
intercropping (Hilje et al., 2001). Intercropping studies in Guatemala have shown that the use of maize as a barrier crop, aubergine as a trap-crop, and poor hosts and non-hosts intercropped with beans did not reduce the densities of $B$. tabaci to economically acceptable levels on the beans (Smith \& McSorley, 2000; Smith et al., 2000). In contrast, cucumber planted as a trapcrop significantly reduced the incidence of tomato yellow leaf curl virus in Jordan (Al-Musa, 1982). Various living mulches are used in many regions to make whitefly host location more difficult (e.g., Smith et al., 2000; Frank \& Liburd, 2005; Hilje \& Stansly, 2008). In Brazil, a dilution effect of $B$. tabaci infestation was observed on tomato associated with native weeds (Bezerra et al., 2004) and in Hawaii, some common cover crops planted with courgette reduced the incidence of squash silverleaf disorder (Manandhar et al., 2009). In Costa Rica, Hilje \& Stansly (2008) observed that B. tabaci abundance and begomoviruses incidence were lower on tomato intercropped with coriander, Coriandrum sativum L. (Apiaceae), and with two other living ground covers (perennial peanuts and whitesnow) compared to conventional methods (insecticide and reflective plastic mulch). Furthermore, coriander provided additional economic returns when sold and was easier to establish in the field. In Brazil, Togni et al. (2009) showed that this intercrop is more effective under organic than conventional management and resulted in a significant reduction of nymphs. Coriander also does not interfere with tomato yield and its flowers attract natural enemies.

From the several intercropping methods described, tomato intercropped with coriander seems to be one of the most promising techniques for the management of $B$. $t a b$ $a c i$, and it is therefore important to know how coriander affects whiteflies behaviour. Coriander has not been recorded as a host of $B$. tabaci or its associated viruses. Its management is easy in the field, as it has a short crop cycle (approximately 50-55 days) until harvest. When added to a crop system, it may help to increase habitat complexity and also to enhance the sensorial stimuli in the environment. Generalist insects, such as whiteflies, need to deal with complex and diverse information in order to benefit from the exploitation of a variety of hosts (Bernays \& Minkenberg,1997). However, when exposed to mixed-sensory stimuli (e.g., intercropping systems), B. tabaci have more difficulty in making a decision (Bernays, 1999) because their decision-making ability is less accurate than in specialist insects (Tosh et al., 2009). These constraints arise from neural limitations on the whiteflies' capacity to integrate information, to the detriment of the sensory processes needed for decision making (Bernays, 2001).
Therefore, the use of coriander intercropped with tomato can make it difficult for B. tabaci to become established in the crop, as the insect has difficulties finding its host in a more heterogeneous and sensorial-complex environment.

The more complex environment offered by coriander most likely conceals the main crop (tomato) visually for whiteflies (Hilje \& Stansly, 2008), but this masking effect may also be broadened to an odour-masking effect on tomato volatiles by coriander volatiles. However, host plant selection by this herbivore is traditionally attributed only to visual cue recognition (Mound, 1962), and the role of semiochemicals in this process has probably been underestimated. Bemisia tabaci recognises specific light wavelengths that induce a phototactic and photokinetic response (ascendent or descendent flights), depending on time of day, sex, host quality, age, and wind, with visual cue recognition being the main factor responsible for whitefly host selection (Blackmer \& Byrne, 1993a,b; Isaacs et al., 1999b). It is possible, however, that plant volatiles can play an important role in host selection by whiteflies. Ying et al. (2003) showed that B. tabaci can recognise several plant odours in Y-shaped olfactometers, without any visual references. Recently, Bleeker et al. (2009) demonstrated that some sesquiterpenes and monoterpenes from tomato plants elicited a response from receptors on the B. tabaci antennae and these volatiles had a strong effect on free-choice bioassays. The identification of attractants, repellents, or masking odours can be used to manipulate $B$. tabaci behaviour and contribute to understanding the ecological mechanisms behind this insect-plant interaction.

The objective of this work was to evaluate whether tomato plant volatiles are used by $B$. tabaci for host selection and whether coriander constitutive volatiles can interfere with finding the host plant (tomato). To do this, we addressed the following questions: (1) Do infochemicals from tomato plants play a role in $B$. tabaci host selection? (2) Can coriander constitutive volatiles reduce the tomato's attractiveness to B. tabaci? (3) If so, do coriander constitutive volatiles have a repellent effect on $B$. tabaci? and (4) Does the intercropping of coriander with tomato reduce the colonisation of $B$. tabaci on tomato plants grown in the greenhouse?

\section{Materials and methods}

\section{Plants and insects}

Tomato plants, var. Duradoro, and coriander plants, var. Verdão, were grown in a greenhouse with natural light at an average temperature of $27 \pm 4{ }^{\circ} \mathrm{C}$, until 30 days after seedlings emerged. During this period, the coriander and tomato are still in the vegetative stage. Tomato plant 
flowering initiates between 40 and 60 days post-germination, while coriander plant flowering starts between 45 and 50 days post-germination. The plants were grown individually inside plastic cages (6 1 in volume) to prevent contamination by plant pathogens and insects and ensure that no mechanical damage was caused during plant manipulation (adapted from Sujii et al., 2008). Coriander plants were planted 15 days before tomatoes, because the coriander plants take more time to grow than tomato plants, and the aim was that both tomato and coriander plants should reach a similar biomass. Bemisia tabaci biotype B was reared in a greenhouse colony $\left(27 \pm 4^{\circ} \mathrm{C}\right)$ from insects of a colony established at Embrapa Vegetables with individuals collected locally in the field near Brasilia, Brazil $\left(15^{\circ} 47^{\prime} \mathrm{S}, 47^{\circ} 55^{\prime} \mathrm{W}\right)$. The individuals were identified as biotype B by using RAPD markers as described in Lima et al. (2002). The whitefly nymphs (fourth instars) used in the bioassays were maintained in plastic dishes containing tomato leaves until adults emerged. These individuals were sexed based on differences on the abdomen, and males and females were reared in separate cages $(30 \times 30 \times 90 \mathrm{~cm})$ with one tomato plant in each one. We collected and separated males and females within $12 \mathrm{~h}$ of emergence, thus preventing mating between newly-emerged adults (Ghanim et al., 2001). Females were exposed to males in a separate chamber containing one tomato plant for $48 \mathrm{~h}$, in order to collect mated individuals for use in the bioassays. We replaced tomato plants that were older than 15 days with other, younger ones. We also maintained a B. tabaci colony as a stock colony, from which nymphs for experiments were collected.

\section{Olfactometer bioassays}

We used a multiple-choice four-arm olfactometer (' $X$ 'type) modified from Vet et al. (1983) to conduct the behavioural experiment with $B$. tabaci. An acrylic block with an ' $X$ '-shaped $(30 \times 30 \times 1 \mathrm{~cm})$ cavity and with a central circular cavity $(5 \mathrm{~cm}$ in diameter) sandwiched between two glass plates, was used as the bioassay arena. Each olfactometer arm was $15 \mathrm{~cm}$ long. As odour sources, we placed single tomato and coriander plants in glass chambers $\left(630 \mathrm{~cm}^{3}\right.$ in volume) and each chamber was connected to the olfactometer via polytetrafluoroethylene (PTFE) tubing. Humidified air was passed through the system at $300 \mathrm{ml} / \mathrm{min}$ in a push-pull system. To check the air flow in all olfactometer arms, we used dry ice in the glass chambers. In order to reduce contamination by soil volatiles, we covered the soil around the plants with aluminium foil. The bioassay was conducted in a heated room $\left(26 \pm 1{ }^{\circ} \mathrm{C}\right.$, r.h. $\left.=70 \pm 5 \%\right)$ with four 40-W fluorescent lights (cool white) on the ceiling of the room.
We used mated and unmated B. tabaci males and females (30 individuals of each) totalling 120 individuals per bioassay. For each bioassay, a single whitefly was introduced in the middle of the arena and observed for $15 \mathrm{~min}$. We registered the first choice and subsequently the period that the insect remained in the chosen arm when it had entered more than $1 \mathrm{~cm}$ into the olfactometer arm and remained there for more than $20 \mathrm{~s}$. Each individual was used only once. We thereby conducted three sets of bioassays: (1) Attractiveness of tomato constitutive volatiles to B. tabaci: in one olfactometer arm we permitted humidified air + tomato volatiles to enter and only humidified air entered the other three arms. If tomato volatiles are attractive to the insects, only one olfactometer arm should be sufficient to attract the majority of the individuals tested over the other three options. We summed the proportion of individuals who first choose humidified air (three olfactometer arms) to compare against tomato volatiles treatment in one arm. (2) Effects of coriander constitutive volatiles on $B$. tabaci selection of tomato as host plant: in this bioassay, we offered one of the following odour sources in each of the four olfactometer arms: (a) tomato constitutive volatiles, (b) coriander constitutive volatiles, (c) tomato + coriander constitutive volatiles, and (d) humidified air. (3) Test of coriander constitutive volatiles' repellence to $B$. tabaci: coriander constitutive volatiles were allowed to enter three olfactometer arms, and in the remaining arm only received humidified air. If coriander volatiles had a repellent effect on $B$. tabaci, the individuals should avoid areas with these volatiles and move to the area with only humidified air. We summed the proportion of individuals who first choose coriander volatiles (three olfactometer arms) to compare against humidified air treatment in one arm. In all experiments, the positions of test volatiles and the control air were changed every three bioassays to avoid bias, and the olfactometer was cleaned with non-soap detergent and rinsed with distilled water every three bioassays.

\section{Greenhouse bioassay}

To evaluate whether $B$. tabaci chooses between single tomatoes and tomatoes intercropped with coriander, a bioassay was performed in a greenhouse $(6 \times 10 \times 3 \mathrm{~m})$, at a temperature of $27 \pm 5{ }^{\circ} \mathrm{C}$ and r.h. $70 \pm 20 \%$. For this experiment, we used the same varieties of tomato and coriander as above, planted in plastic pots ( 0.251 in volume). Coriander plants were planted 15 days before tomatoes, as described above. The tomato and coriander plants were grouped in paired experimental plots, forming two treatments: (1) tomato monoculture and (2) tomato intercropped with coriander, with four replicates of each one. To circumvent any possible positional preference of the 
insects, the plots were positioned in a way that each plot occupied a different position in the greenhouse. Each experimental plot was formed by 25 tomato plants spaced $30 \mathrm{~cm}$ apart, with a distance of $50 \mathrm{~cm}$ between rows (five plants/row). In the intercropping treatments, one coriander plant was positioned between each pair of tomatoes, leaving a space of $15 \mathrm{~cm}$ between coriander and tomato plants, totalling 16 coriander plants per plot $(n=$ four plants/row). We left a space of $2.5 \mathrm{~m}$ between the experimental plots. At 30 days after the tomato plants emerged, 1000 whiteflies were released into the greenhouse, between the experimental plots. After $2 \mathrm{~h}$, the number of whiteflies per plant in each experimental plot was counted, assuming that by the end of this period the insects had made their first choice of an experimental plot. After $48 \mathrm{~h}$, the same procedure was repeated, in the same plants, to check the insect population distribution between the experimental plots subsequent to their first choice. To evaluate the oviposition preference of B. tabaci females, the tomato plants were removed at 15 days post-release and the number of nymphs per plant counted to obtain the mean number of nymphs per plot in each treatment (tomato monoculture or intercropped with coriander).

\section{Statistical analysis}

The proportion of B. tabaci individuals' first choice and the residence time in olfactometer arms with humidified air (three arms) and coriander volatiles (three arms) in bioassay 1 and 3, respectively, were summed. To determine the attractiveness of tomato constitutive volatiles to B. tabaci (olfactometer bioassay 1 ), the influence of coriander volatiles on the attractiveness of tomato volatiles to $B$. tabaci (olfactometer bioassay 2), and if $B$. tabaci recognises coriander constitutive volatiles as a negative stimulus (olfactometer bioassay 3 ) we used the $\chi^{2}$ goodness-of-fit test to compare the percentage of observed individuals' first choices with the expected ratios in each treatment (Krebs, 1999). The residence time in olfactometer arms in each bioassay was compared using a paired t-test (bioassays 1 and 3) or using the Kruskal-Wallis test followed by Dunn's test (bioassay 2) (Southwood \& Henderson, 2000). The tests were performed separately for each experiment, for males or females, and for mated or unmated insects. To investigate whether individuals who first chose tomato volatiles (bioassay 1) tended to stay longer in these areas than individuals that first chose humidified air, we applied an analysis considering the residence time in tomato volatiles. The individuals were separated into two groups: (1) individuals who first chose tomato volatiles and (2) individuals who first chose humidified air. Then, we compared the residence time in tomato volatiles between these two groups using a Mann-Whitney test without considering the sex of the individuals. In the greenhouse bioassay, we evaluated the mean number of $B$. tabaci adults and nymphs per plant in each experimental plot, which was compared separately using a paired t-test. All tests were performed using the statistical software packages SigmaStat (Systat Software, 2004) and PAST (Hammer et al., 2001).

\section{Results}

Attractiveness of tomato constitutive volatiles to Bemisia tabaci

In the multiple choice olfactometer, $B$. tabaci individuals recognised and moved toward the areas with tomato volatiles (first choice) rather than areas with only humidified air (Figure 1A). This pattern was observed in unmated females $\left(\chi^{2}=32.67\right.$, d.f. $\left.=1, \mathrm{P}<0.0001\right)$, mated females $\left(\chi^{2}=2.70\right.$, d.f. $\left.=1, \mathrm{P}<0.0001\right)$, unmated males $\left(\chi^{2}=\right.$ 34.27, d.f. $=1, \mathrm{P}<0.0001)$, and mated males $\left(\chi^{2}=22.8\right.$, d.f $=1, \mathrm{P}<0.0001$ ) (Figure 1A). In general, the whiteflies chose tomato volatiles in $65.8 \pm 5.0 \%$ (mean $\pm \mathrm{SD}$ ) of the observations, suggesting that tomato volatiles are attractants to B. tabaci. Moreover, all individuals observed made a choice in all olfactometer bioassays.

After recognising, selecting, and moving towards areas with tomato volatiles in the olfactometer, the insects tended to stay in these areas. Whiteflies in this bioassay took $116.9 \pm 31.97 \mathrm{~s}$ (mean $\pm \mathrm{SD}$ ) to enter an olfactometer arm; this time and the time that individuals moved among olfactometer arms was discounted from the total time (900 s). The proportion of $B$. tabaci first choice of humidified air (three olfactometer arms) was summed separately for each sex. It was performed for unmated females $(t=2.86$, d.f. $=3, P=0.007)$, mated females $(\mathrm{t}=2.98$, d.f. $=3, \mathrm{P}=0.006)$, unmated males $(\mathrm{t}=5.49$, d.f. $=3, P<0.0001)$ and mated males $(t=3.59$, d.f. $=3$, $\mathrm{P}=0.001$ ). Thus, $B$. tabaci, independent of sex, remained for significantly longer periods in olfactometer arms with tomato volatiles rather than humidified air (Figure 2). Apparently, the individuals entered areas with humidified air randomly. Furthermore, whiteflies that first chose the arm with the tomato volatiles spent significantly more time in areas with these volatiles than individuals that first chose an arm with humidified air (Figure 3), suggesting the attraction and retention of $B$. tabaci by tomato volatiles.

\section{Effects of coriander constitutive volatiles on Bemisia tabaci selection of tomato as host}

When coriander volatiles were mixed with tomato volatiles, we observed a reduction in the tomato volatiles' attractiveness to $B$. tabaci females. Females (mated and unmated) preferred the areas with only tomato 

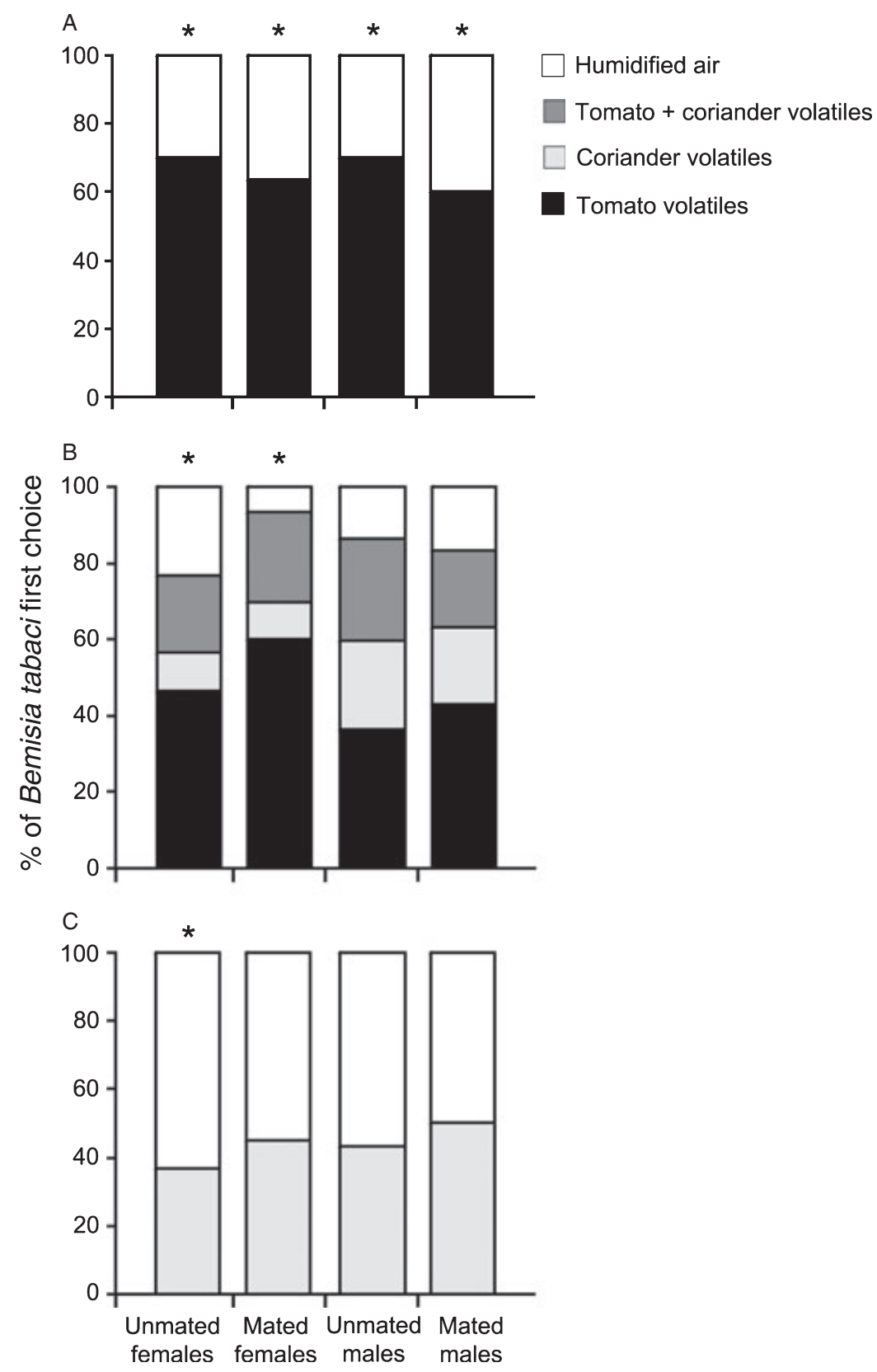

Figure 1 Response of Bemisia tabaci biotype $B$, mated and unmated, males and females to (A) tomato constitutive volatiles, offered in one olfactometer arm, and humidified air in the other three arms, (B) tomato constitutive volatiles, tomato + coriander constitutive volatiles, coriander constitutive volatiles, and humidified air, and $(\mathrm{C})$ coriander constitutive volatiles offered in three olfactometer arms, with humidified air offered in one olfactometer arm in a multiple-choice olfactometer. The percentage of first choice of each experimental group was compared among treatments in each bioassay using the $\chi^{2}$ goodness-of-fit test. ${ }^{*}$ indicates significant difference among treatments $(\mathrm{P}<0.05)$. In each bioassay we observed 120 individuals (30 mated or unmated individuals per sex).

volatiles, followed by tomato + coriander volatiles, when we analysed the individual's first choices. The areas with coriander volatiles only and with humidified air were less often chosen than the other areas and the proportion of individuals that chose these treatments did not differ significantly (Figure 1B). This pattern was significant for unmated females $\left(\chi^{2}=8.67\right.$, d.f. $\left.=1, \mathrm{P}=0.034\right)$ and mated females $\left(\chi^{2}=21.47\right.$, d.f. $\left.=1, \mathrm{P}<0.001\right)$. However, the unmated $\left(\chi^{2}=3.33\right.$, d.f. $\left.=1, \mathrm{P}=0.34\right)$ and mated males $\left(\chi^{2}=5.47\right.$, d.f. $\left.=1, P=0.14\right)$ did not show a preference for any treatment (Figure 1B).
As observed in B. tabaci first choice in this bioassay, the females (mated and unmated) remained for significantly longer periods in olfactometer arms where tomato volatiles were present. The $B$. tabaci females also remained for significantly shorter periods in olfactometer arms where the tomato + coriander volatiles were present than in arms with only tomato volatiles. We observed the following gradient of residence time by $B$. tabaci females in the treatments (Table 1): tomato volatiles $>$ tomato + coriander volatiles $>$ coriander volatiles $=$ humidified air. Bemisia tabaci unmated males followed the same pattern as the 


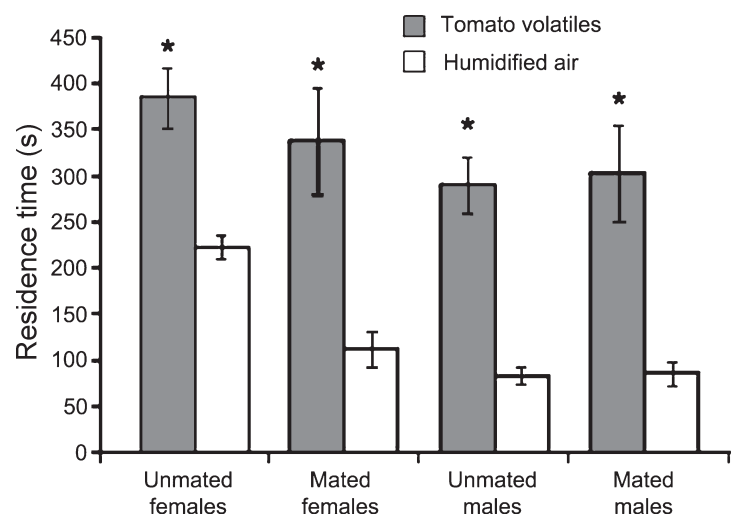

Figure 2 Comparison of residence time (mean \pm SE) of Bemisia tabaci biotype B, mated and unmated, males and females in areas with tomato constitutive volatiles (one olfactometer arm) and with humidified air (three olfactometer arms) in a multiplechoice olfactometer. ${ }^{*}$ indicates significant difference among the treatments (paired t-test: unmated females: $\mathrm{t}=2.863, \mathrm{P}=0.007$; $\mathrm{n}=30$; mated females: $\mathrm{t}=2.982, \mathrm{P}=0.006 ; \mathrm{n}=30$; unmated males: $\mathrm{t}=5.489, \mathrm{P}<0.0001 ; \mathrm{n}=30$; and mated males: $\mathrm{t}=3.589$, $\mathrm{P}=0.001 ; \mathrm{n}=30)$.

females, whereas the mated males' residence time was similar in all olfactometer arms (Table 1). In this bioassay, the individuals took $127.7 \pm 48.27 \mathrm{~s}$ to make their first choice.

\section{Repellence of coriander constitutive volatiles to $B$. tabaci}

Only unmated female B. tabaci avoided the olfactometer arms in which coriander volatiles were present (bioassay 3 ) and moved toward the areas with humidified air $\left(\chi^{2}=23.60\right.$; d.f. $\left.=1, \mathrm{P}<0.001\right)$ (first choice). Mated females $\left(\chi^{2}=3.60\right.$, d.f. $\left.=1, \mathrm{P}=0.308, \mathrm{n}=30\right)$ and males in general (unmated $\chi^{2}=7.88$, d.f. $=1, \mathrm{P}=0.308$; and mated $\chi^{2}=11.06$, d.f. $=1, \mathrm{P}=0.308$ ) did not recognise the coriander volatiles as a negative stimulus. The proportion of individuals that first chose coriander volatiles was similar to the proportion of individuals that first chose humidified air (Figure 1C). The residence time of unmated females was higher in olfactometer arms with humidified air than with coriander volatiles, but the residence time of mated females and of both mated and unmated males did not differ between these areas. The proportion of B. tabaci first choice of humidified air (three olfactometer arms) was summed separately for each sex. These variables were compared using the paired t-test. It was performed for unmated females $(t=5.60$, d.f. $=3$, $\mathrm{P}<0.0001)$, mated females $(\mathrm{t}=-1.77$, d.f. $=3, \mathrm{P}=$ $0.089)$, unmated males $(\mathrm{t}=-1.45$, d.f. $=3, \mathrm{P}=0.157)$, and mated males $(\mathrm{t}=-1.01$, d.f. $=3, \mathrm{P}=0.323)$, totalling 120 individuals observed. These results indicate that coriander volatiles were not a negative stimulus to $B$. tabaci

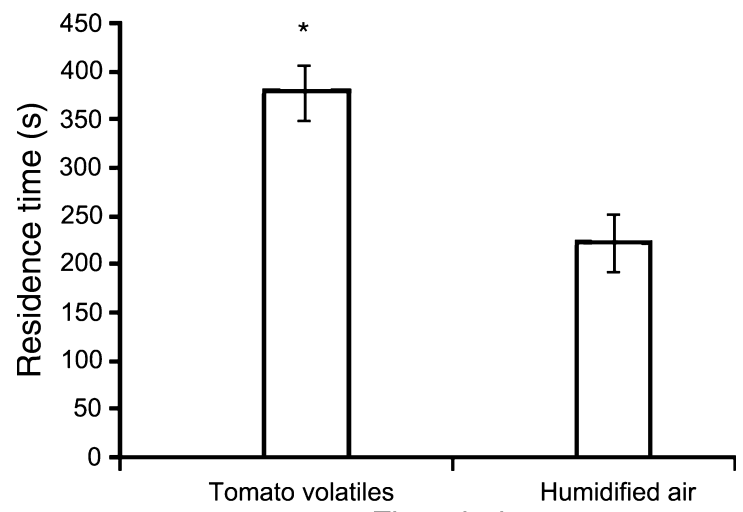

First choice

Figure 3 Comparison of residence time (mean \pm SE) of Bemisia tabaci biotype $\mathrm{B}$ in a multiple-choice olfactometer area with tomato constitutive volatiles after their first choice for the area with tomato volatiles (one olfactometer arm) or for the area with humidified air (three olfactometer arms). ${ }^{*}$ indicates significant difference between the two groups (Mann-Whitney $\mathrm{U}=1053$, $\mathrm{P}=0.0017 ; \mathrm{n}=120)$.

(Figure 4). Furthermore, they took $118.2 \pm 7.95 \mathrm{~s}$ to make their first choice.

\section{Colonisation and establishment of $B$. tabaci on tomato intercropped with coriander}

In the greenhouse experiment, $B$. tabaci showed a clear preference for tomatoes planted in monoculture over tomatoes intercropped with coriander plants. Two hours after B. tabaci release into the greenhouse, the majority of individuals had moved to the tomato monoculture treatment (Table 2). Exactly the same pattern was observed 48 h post-release (Table 2). Moreover, the colonisation of monocultured tomato plants by $B$. tabaci adults was reflected in a higher number of nymphs per plant in the tomato monoculture plots than plots containing tomatoes intercropped with coriander (Table 2).

\section{Discussion}

Our results demonstrated that tomato constitutive volatiles can play an important role in $B$. tabaci biotype B host plant selection, and that this has consequences for its population dynamics. Coriander constitutive volatiles reduced the whitefly females' preference for tomato volatiles, consequently reducing $B$. tabaci colonisation and establishment on tomato plants intercropped with coriander plants. Volatiles from coriander plants, however, were not recognised as a negative stimulus to $B$. tabaci, suggesting that these volatiles had an odour-masking effect of tomato constitutive volatiles rather than a repellent effect. 
Table 1 Comparison of the time (mean \pm SE) that Bemisia tabaci biotype B, mated and unmated, males and females stayed in areas treated with tomato constitutive volatiles, tomato + coriander constitutive volatiles, coriander constitutive volatiles, and humidified air in a multiple-choice olfactometer. These variables were compared using the Kruskal-Wallis test followed by Dunn's test: unmated females: $\mathrm{H}=21.34$, d.f. $=3, \mathrm{P}<0.001 ; \mathrm{n}=30$; mated females: $\mathrm{H}=43.98$, d.f. $=3, \mathrm{P}<0.001 ; \mathrm{n}=30$; unmated males: $\mathrm{H}=51.45$, d.f. $=3$, $\mathrm{P}=0.161 ; \mathrm{n}=30$; and mated males: $\mathrm{H}=16.89$, d.f. $=3, \mathrm{P}<0.001 ; \mathrm{n}=30$

\begin{tabular}{|c|c|c|c|c|}
\hline Sex & Tomato volatiles & Tomato + coriander volatiles & Coriander volatiles & Humidified air \\
\hline \multicolumn{5}{|l|}{ Females } \\
\hline Unmated & $259.09 \pm 44.95 \mathrm{a}$ & $180.96 \pm 38.13 c$ & $154.48 \pm 28.21 b$ & $79.39 \pm 23.15 b$ \\
\hline Mated & $318.49 \pm 56.15 \mathrm{a}$ & $173.19 \pm 36.68 c$ & $72.99 \pm 23.75 b$ & $124.48 \pm 46.47 b$ \\
\hline \multicolumn{5}{|l|}{ Males } \\
\hline Unmated & $375.53 \pm 47.5 \mathrm{a}$ & $107.99 \pm 17.71 \mathrm{c}$ & $58.92 \pm 17.71 b$ & $25.93 \pm 11.57 b$ \\
\hline Mated & $217.34 \pm 52.25 \mathrm{a}$ & $98.1 \pm 36.2 \mathrm{a}$ & $132.52 \pm 38.83 a$ & $146.08 \pm 41.93 \mathrm{a}$ \\
\hline
\end{tabular}

Means within a row followed by the same letter do not differ significantly (Dunn's test: $\mathrm{P}<0.05$ ).

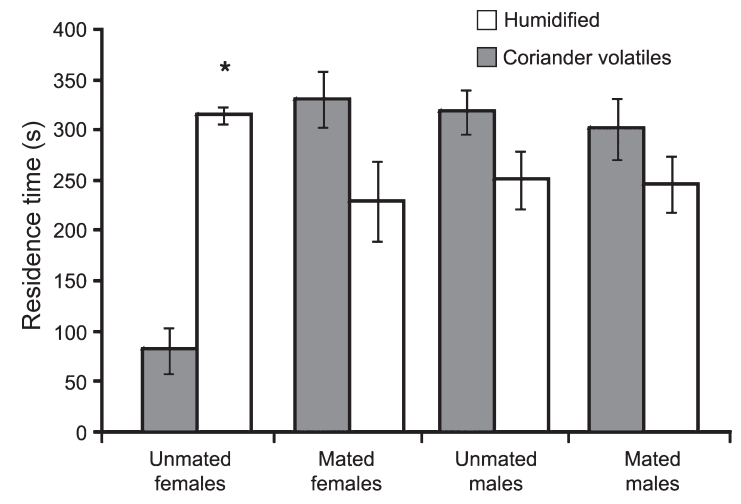

Figure 4 Comparison of residence time (mean \pm SE) of Bemisia tabaci biotype $\mathrm{B}$, mated and unmated, males in areas with coriander constitutive volatiles (three olfactometer arms) and with humidified air (one olfactometer arm) in a multiple-choice olfactometer. The proportion of B. tabaci first choice of humidified air (three olfactometer arms) was summed separately for each sex. ${ }^{*}$ indicates significant difference among the treatments (paired t-test: unmated females: $\mathrm{t}=5.60, \mathrm{P}<0.0001 ; \mathrm{n}=30$ ).

Moreover, this study supports the hypothesis that infochemicals from plants can act together with visual cue recognition in B. tabaci host plant selection.

We showed that $B$. tabaci males and females recognised tomato constitutive volatiles and moved towards the areas of highest concentration of these volatiles (taxic effect), even without a visual reference, remaining in these areas for a longer period than in areas with only humidified air, which indicated that the constitutive volatiles of tomato may have a kinetic effect on host searching behaviour (Figures 1-2). A relationship between residence time in each olfactometer arm and first choice of tomato was also observed (Figure 3). Ying et al. (2003), using a Y-shaped olfactometer, demonstrated that B. tabaci biotype B is
Table 2 Bemisia tabaci biotype B colonisation and establishment in experimental plots with tomato monoculture and with tomatoes intercropped with coriander in greenhouse $\left(27 \pm 5^{\circ} \mathrm{C}\right)$. Each treatment had four paired replicates. One thousand whiteflies were released into the greenhouse and the number of adults per plot was evaluated after 2 and $48 \mathrm{~h}$. The number of nymphs per plant in each experimental plot was evaluated after 15 days post-release of adults. Variables were compared between the treatments with the paired t-test: adults' colonisation after $2 \mathrm{~h}$ $(\mathrm{t}=9.24$, d.f. $=3, \mathrm{P}<0.0001 ; \mathrm{n}=100)$ and after $48 \mathrm{~h}(\mathrm{t}=7.47$, d.f. $=3, \mathrm{P}<0.0001 ; \mathrm{n}=97)$, and number of nymphs per plant in each experimental plot $(\mathrm{t}=8.06$, d.f. $=3, \mathrm{P}<0.0001 ; \mathrm{n}=93)$

\begin{tabular}{lccc}
\hline & \multicolumn{2}{c}{ Adults } & \\
\cline { 2 - 3 } Treatment & $2 \mathrm{~h}$ & $48 \mathrm{~h}$ & Nymphs \\
\hline $\begin{array}{l}\text { Tomato } \\
\text { monoculture }\end{array}$ & $4.25 \pm 2.51 \mathrm{a}$ & $3.79 \pm 2.34 \mathrm{a}$ & $10.49 \pm 3.74 \mathrm{a}$ \\
$\begin{array}{l}\text { Tomato } \\
\text { intercropped }\end{array}$ & $1.48 \pm 1.31 \mathrm{~b}$ & $1.62 \pm 1.51 \mathrm{~b}$ & $4.16 \pm 1.72 \mathrm{~b}$ \\
with coriander & & & \\
\hline
\end{tabular}

Means within a column followed by a different letter differ significantly $(\mathrm{P}<0.05)$.

attracted by plant volatiles from five distinct host plant species, including tomato. Bleeker et al. (2009) collected, identified, and isolated several semiochemicals derived from wild tomatoes and used them for electroantennography and free-choice bioassays with $B$. tabaci biotypes $B$ and Q. They observed that several terpenoids are involved in B. tabaci-tomato interaction, with different ranks of attraction varying with the kind of terpenoids. Furthermore, certain sesquiterpenes elicited a response from B. tabaci antennae.

Other studies investigating $B$. tabaci host plant selection have focused mainly on the preference by various genotypes of the same plant (Fancelli et al., 2003; Bird \& 
Kruger, 2006; Oriani et al., 2008), reproductive rates of whiteflies on different host plant species (Costa et al., 1991; Villas-Bôas et al., 2002), insect bionomy on various hosts, (Nava-Camberos et al., 2001), effects of insecticides on insect behaviour (Isaacs et al., 1999a), effects of vigorous and stressed plants on host plant selection and insect development (Inbar et al., 2001), effect of time of day, sex, age, and host quality on flight modulation and consequently on host plant selection (Blackmer \& Byrne, 1993a,b), and visual cue recognition (Mound, 1962, 1963). However, the results presented here suggest that plant volatiles could also contribute to host plant selection. It is possible that B. tabaci locate their host (tomato) during flight using visual cues and that integrating the information with olfactory cues can improve host targeting.

When B. tabaci was exposed to tomato volatiles simultaneously with coriander volatiles, we observed that the individuals' first choice was negatively affected, apparently reducing their ability to identify volatiles of tomato plants (Figure 1B). This pattern was significant only for females (mated and unmated), suggesting that host plant selection in B. tabaci males could be conditioned by other factors. These differences between $B$. tabaci sexes can be related to the differences in host use and confirms the general pattern observed in some insects that females are more attracted to host volatiles than males (Szendrei \& Rodriguéz-Saona, 2010).

Except for mated males, individuals stayed a shorter time in areas with coriander + tomato volatiles than in areas with only tomato volatiles, thereby confirming a reduction in the preference for tomato volatiles due to coriander volatiles (Table 1). However, males and females were apparently indifferent to coriander volatiles when these were presented alone, because the individuals spent similar periods in areas with these volatiles and areas with only humidified air.

Generalist insects such as $B$. tabaci usually benefit from the exploitation of a mixed diet of different host plant species (Bernays \& Minkenberg, 1997; Bernays, 2001; Tosh et al., 2009), although their performance is enhanced when they grow on a single preferred host (Bernays, 1999; Bird \& Kruger, 2006). Considering that coriander is not a host of $B$. tabaci, the positive sensorial stimulus from a host (tomato) together with an indifferent or a negative stimulus from a non-host plant (coriander) makes the insect's host decision-making more difficult. This phenomenon, called 'odour masking' was first observed in the Colorado potato beetle, Leptinotarsa decemlineata (Say) by Thiéry \& Visser (1987) and has been suggested as a mechanism to reduce phytophagous populations in polycultures (Schoonhoven et al., 2005; Schröder \& Hilker, 2008). Moreover, coriander plants can be attractive to some natural enemies, such as some Coccinellidae, due to alternative food resources such as polen during flowering. These factors can enhance the predation risk for whiteflies and increase the cost of that using the host tomato as a resource (Mayer et al., 2002; Randlkofer et al., 2007). This hypothesis is supported by previous studies demonstrating that $B$. tabaci can recognise infochemicals from predatory mites and avoid plants with these arthropods (Nomikou et al., 2003).

Despite this reduction in preference for tomato volatiles when coriander was added, coriander volatiles alone were not repellent to the majority of individuals observed. Only unmated females tended to avoid areas with coriander constitutive volatiles, moving to areas with only humidified air (Figure 1C). Repellence or deterrence of plant volatiles to $B$. tabaci is not well established, but it is known that individuals avoid plant species which contain aromatic oils, such as ginger oil (Zhang et al., 2004). Therefore, if coriander is sowed before tomato plants, it can help prevent the establishment of newly emerged unmated females from other areas, in the crop, through visual and olfactory camouflage.

Avoidance of tomatoes intercropped with coriander in B. tabaci was evident in the greenhouse bioassay (Table 2). In this bioassay, individuals were exposed to visual and odour stimuli, unlike in olfactometer bioassays where the whiteflies were confronted with plants odours without a visual reference. We observed a greater number of adults colonising and establishing themselves in tomato monoculture plots than in plots of tomato intercropped with coriander. This same pattern of avoidance of tomato intercropped with coriander was observed in previous field work in Costa Rica (Hilje \& Stansly, 2008) and in Brazil under conventional and organic management (Togni et al., 2009). We also observed a lower number of nymphs per plant in plots with coriander than in plots with only tomatoes. Similarly, Costa \& Bleicher (2006) observed a reduction in the number of $B$. tabaci nymphs when melon (Cucumis melo L.) or watermelon (Citrullus lanatus Thumb.) plants were associated with coriander plants in a greenhouse (Costa \& Bleicher, 2006). In these cases, coriander plants probably acted as 'inappropriate' landing sites (negative stimulus) (Finch \& Collier, 2000) and the whiteflies moved to single host plant areas. These results reinforce that coriander can be used in B. tabaci management in various agroecosystems.

\section{Acknowledgments}

The authors are grateful to 'Coordenação de Aperfeiçoamento de Pessoal de Nível Superior' (CAPES), to 'Fundação de Apoio a Pesquisa do Distrito Federal' (FAP-DF) 
(Process $N^{\circ}$ 193.000.299/2007) and 'Centro de Desenvolvimento da Agricultura Orgânica no Distrito Federal' (CDTORG-DF), which have provided financial support for the project, and to Embrapa Genetic Resources and Biotechnology and Embrapa Vegetables for providing material, structural and technical support. We are also grateful to Leonardo F. Langer, Michely S. Aquino, and Kelly R. Cavalcante for help in running bioassays.

\section{References}

Al-Musa A (1982) Incidence, economic importance, and control of tomato yellow leaf curl in Jordan. Plant Disease 66: 561-563.

Bernays EA (1999) When host choice is a problem for a generalist herbivore: experiments with the whitefly, Bemisia tabaci. Ecological Entomology 24: 260-267.

Bernays EA (2001) Neural limitation in phytophagous insects: implications for diet breadth and evolution of host affiliation. Annual Review of Entomology 46: 703-727.

Bernays EA \& Minkenberg OPJM (1997) Insect herbivores: different reasons for being a generalist. Ecology 78: 1157-1169.

Bezerra MAS, Oliveira MRV \& Vasconcelos SD (2004) Does the presence of weeds affect Bemisia tabaci Gennadius (Hemiptera: Aleyrodidae) infestation on tomato plants in a semi-arid agroecosystem? Neotropical Entomology 33: 769-775.

Bird TL \& Kruger K (2006) Response of the polyphagous whitefly Bemisia tabaci B-biotype (Hemiptera: Aleyrodidae) to crop diversification - influence of multiple sensory stimuli on activity and fecundity. Bulletin of Entomological Research 96: 15-23.

Blackmer JL \& Byrne DN (1993a) Flight behaviour of Bemisia tabaci in a vertical flight chamber: effect of time of day, sex, age and host quality. Physiological Entomology 18: 223-232.

Blackmer JL \& Byrne DN (1993b) Environmental and physiological factors influencing phototactic flight of Bemisia tabaci. Physiological Entomology 18: 336-342.

Bleeker PM, Diergaarde PJ, Ament K, Guerra J, Weidner M et al. (2009) The role of specific tomato volatiles in tomato-whitefly interaction. Plant Physiology 151: 925-935.

Byrne DN \& Bellows TS Jr (1991) Whitefly biology. Annual Review of Entomology 36: 431-457.

Castle SJ, Henneberry TJ \& Toscano NC (1996) Suppression of Bemisia tabaci (Homoptera: Aleyrodidae) infestations in cantaloupe and cotton with sprinkler irrigation. Crop Protection 15: 657-663.

Costa RS \& Bleicher E (2006) Comportamento da mosca-branca (Bemisia tabaci biótipo B) em sistemas de plantio de coentro, melancia e melão. Revista Ciência Agronômica 37: 195-199.

Costa HS, Brown JK \& Byrne DN (1991) Host plant selection by the whitefly, Bemisia tabaci (Gennadius), (Hom., Aleyrodidae) under greenhouse conditions. Journal of Applied Entomology 112: 146-152.

Fancelli M, Vendramim JD, Lourenção AL \& Dias CTS (2003) Atratividade e preferência para oviposição de Bemisia tabaci
(Gennadius) (Hemiptera: Aleyrodidae) biótipo B em genótipos de tomateiro. Neotropical Entomology 32: 319-328.

Finch S \& Collier RH (2000) Host-plant selection by insects - a theory based on 'appropriate/inappropriate landings' by pest insects of cruciferous plants. Entomologia Experimentalis et Applicata 96: 91-102.

Frank DL \& Liburd OE (2005) Effects of living and synthetic mulch on the population dynamics of whiteflies and aphids, their associated natural enemies, and insecttransmitted plant diseases in zucchini. Environmental Entomology 34: 857-865.

Gerling D, Alomar O \& Arno J (2001) Biological control for Bemisia tabaci using predators and parasitoids. Crop Protection 20: 835-852.

Ghanim M, Rosell RC, Campbell LR, Czosnek H, Brown JK \& Ullman DE (2001) Digestive, salivary and reproductive organs of Bemisia tabaci (Gennadius) (Hemiptera: Aleyrodidae) B type. Journal of Morphology 248: 22-40.

Hammer O, Harper DAT \& Ryan PD (2001) Paleontological statistics software package for education and data analyses. Palaeontologia Electronica 4: 9.

Hilje L \& Stansly PA (2008) Living ground covers for management of Bemisia tabaci (Gennadius) (Homoptera: Aleyrodidae) and tomato yellow mottle virus in Costa Rica. Crop Protection 27: 10-16.

Hilje L, Costa HS \& Stansly PA (2001) Cultural practices for managing Bemisia tabaci and associated viral diseases. Crop Protection 20: 801-812.

Inbar M \& Gerling D (2008) Plant-mediated interactions between whiteflies, herbivores, and natural enemies. Annual Review of Entomology 53: 431-448.

Inbar M, Doostdar H \& Mayer RT (2001) Suitability of stressed and vigorous plants to various insect herbivores. Oikos 94: 228-235.

Isaacs R, Cahil M \& Byrne DN (1999a) Host plant evaluation behavior of Bemisia tabaci and its modification by external or internal uptake of imidacloprid. Physiological Entomology 24: 101-108.

Isaacs R, Willis MA \& Byrne DN (1999b) Modulation of whitefly take-off and flight orientation by wind speed and visual cues. Physiological Entomology 24: 311-318.

Jones D (2003) Plant viruses transmitted by whiteflies. European Journal of Plant Pathology 109: 197-221.

Krebs CJ (1999) Ecological Methodology, 2nd edn. Addison Wesley, Menlo Park, CA, USA.

Lima LHC, Campos L, Moretzsohn MC, Návia D \& Oliveira MRV (2002) Genetic diversity of Bemisia tabaci (Genn.) populations in Brazil revealed by RAPD markers. Genetics and Molecular Biology 25: 217-223.

Manandhar R, Hooks GRR \& Wright MG (2009) Influence of cover crop and intercrop systems on Bemisia argentifolii (Hemiptera: Aleyrodidae) infestation and associated squash silverleaf disorder in zucchini. Environmental Entomology 38: 442-449.

Mayer RT, Inbar M, McKenzie CL, Shatters R, Borowicz V et al. (2002) Multitrophic interactions of the silverleaf whitefly, host 
plants, competing herbivores, and phytopathogens. Archives of Insect Biochemistry and Physiology 51: 151-169.

Morales F \& Jones PG (2004) The ecology and epidemiology of whitefly-transmitted viruses in Latin America. Virus Research 10: 57-65.

Mound LA (1962) Studies on the olfaction and colour sensitivity of Bemisia tabaci (Genn.) (Homoptera, Aleyrodidae). Entomologia Experimentalis et Applicata 5: 99-104.

Mound LA (1963) Host-correlated variation in Bemisia tabaci (Gennadius) (Homoptera: Aleyrodidae). Proceedings of the Royal Entomological Society of London A 38: 171-180.

Naranjo SE (2001) Conservation and evaluation of natural enemies in IPM systems for Bemisia tabaci. Crop Protection 20: 835-852.

Nava-Camberos U, Riley DG \& Harris MK (2001) Temperature and host plant effects on development, survival, and fecundity of Bemisia argentifolii (Homoptera: Aleyrodidae). Environmental Entomology 30: 55-63.

Nomikou M, Janssen A \& Sabelis MW (2003) Herbivore host plant selection: whitefly learns to avoid hosts that harbour predators of her offspring. Oecologia 136: 484-488.

Oliveira MRV, Henneberry TJ \& Anderson P (2001) History, current status and collaborative research projects for Bemisia tabaci. Crop Protection 20: 709-723.

Oriani MA, Vendramim JD \& Brunherotto R (2008) Aspectos biológicos de Bemisia tabaci (Genn.) biótipo B (Hemiptera: Aleyrodidae) em seis genótipos de feijoeiro. Neotropical Entomology 37: 191-195.

Randlkofer B, Obermaier E \& Meiners T (2007) Mother's choice of the oviposition site: balancing risk of egg parasitism and need of food supply for the progeny with an infochemical shelter? Chemoecology 17: 177-186.

Schoonhoven LM, van Loon JAJ \& Dicke M (2005) Insect-Plant Biology, 2nd edn. Oxford University Press, Oxford, UK.

Schröder R \& Hilker M (2008) The relevance of background odor in resource location by insects: a behavioral approach. BioScience 58: 308-316.

Smith HA \& McSorley R (2000) Potential of field corn as a barrier crop and eggplant as a trap crop for management of Bemisia argentifolii (Homoptera: Aleyrodidae) on common bean in north Florida. Florida Entomologist 83: 145-158.

Smith HA, Koenig RL, McAuslane HJ \& McSorley R (2000) Effect of silver reflective mulch and summer squash trap crop on densities of immature Bemisia argentifolii (Homoptera: Aleyrodidae) on organic bean. Journal of Economic Entomology 93: 726-731.

Southwood TRE \& Henderson PA (2000) Ecological Methods, 3rd edn. Blackwell, Oxford, UK.

Sujii ER, Togni PHB, Nakasu EYT, Pires CSS, Paula DP \& Fontes EMG (2008) Impacto do algodoeiro Bt na dinâmica do pulgão-do-algodoeiro em casa de vegetação. Pesquisa Agropecuária Brasileira 43: 1251-1256.

Systat Software (2004) SigmaStat 3.1 for Windows. INSO, Richmond, CA, USA.

Szendrei Z \& Rodriguéz-Saona C (2010) A meta-analysis of insect pest behavioural manipulation with plant volatiles. Entomologia Experimentalis et Applicata 134: 201-210.

Thiéry D \& Visser JH (1987) Misleading the Colorado potato beetle with an odour blend. Journal of Chemical Ecology 13: 1139-1146.

Togni PHB, Frizzas MR, Medeiros MA, Nakasu EYT, Pires CSS \& Sujii ERS (2009) Dinâmica populacional de Bemisia tabaci biótipo B em tomate monocultivo e consorciado com coentro sob cultivo organic e convencional. Horticultura Brasileira 27: 183-188.

Tosh PR, Krause J \& Ruxton GD (2009) Theoretical predictions strongly support decision accuracy as a major driver of ecological specialization. Proceedings of the National Academy of Sciences of the USA 106: 5698-5702.

Ucko OS, Cohen S \& Ben-Joseph R (1998) Prevention of virus epidemics by a crop-free period in the Arava region of Israel. Phytoparasitica 26: 313-321.

Vet LEM, van Lenteren JC, Heymans M \& Meelis E (1983) An airflow olfactometer for measuring olfactory responses of hymenopterous insects parasitoids and other small insects. Physiological Entomology 8: 97-106.

Villas-Bôas GL, França FH \& Macedo N (2002) Potencial biótico da mosca-branca Bemisia argentifolii a diferentes plantas hospedeiras. Horticultura Brasileira 20: 71-79.

Ying J, Huang J, Rui-yan M \& Ju-cai H (2003) Host plant preferences of Bemisia tabaci Gennadius. Insect Science 10: 109-114.

Zhang W, McAuslane HJ \& Schuster DJ (2004) Repellency of ginger oil to Bemisia argentifolii (Homoptera: Aleyrodidae) on tomato. Ecotoxicology 97: 1310-1318. 